NATIONAL LABORATORY

MANAGED BY UT-BATTELLE

FOR THE DEPARTMENT OF ENERGY

\title{
Domestic and International Nuclear Energy Voluntary Consensus Standards Needs
}

\section{January 2013}

Prepared by

C. M. Hopper, retired

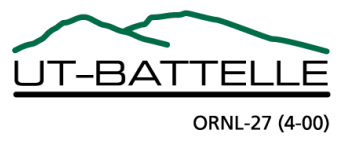




\section{DOCUMENT AVAILABILITY}

Reports produced after January 1, 1996, are generally available free via the U.S. Department of Energy (DOE) Information Bridge.

Web site http://www.osti.gov/bridge

Reports produced before January 1, 1996, may be purchased by members of the public from the following source.

National Technical Information Service

5285 Port Royal Road

Springfield, VA 22161

Telephone 703-605-6000 (1-800-553-6847)

TDD 703-487-4639

Fax 703-605-6900

E-mail info@ntis.gov

Web site http://www.ntis.gov/support/ordernowabout.htm

Reports are available to DOE employees, DOE contractors, Energy Technology Data Exchange (ETDE) representatives, and International Nuclear Information System (INIS) representatives from the following source.

Office of Scientific and Technical Information

P.O. Box 62

Oak Ridge, TN 37831

Telephone 865-576-8401

Fax 865-576-5728

E-mail reports@osti.gov

Web site http://www.osti.gov/contact.html

This report was prepared as an account of work sponsored by an agency of the United States Government. Neither the United States Government nor any agency thereof, nor any of their employees, makes any warranty, express or implied, or assumes any legal liability or responsibility for the accuracy, completeness, or usefulness of any information, apparatus, product, or process disclosed, or represents that its use would not infringe privately owned rights. Reference herein to any specific commercial product, process, or service by trade name, trademark, manufacturer, or otherwise, does not necessarily constitute or imply its endorsement, recommendation, or favoring by the United States Government or any agency thereof. The views and opinions of authors expressed herein do not necessarily state or reflect those of the United States Government or any agency thereof. 
Reactor and Nuclear Systems Division

\title{
DOMESTIC AND INTERNATIONAL NUCLEAR ENERGY VOLUNTARY CONSENSUS STANDARDS NEEDS
}

\author{
C. M. Hopper, retired*
}

Date Published: January 2013

\author{
Prepared by \\ OAK RIDGE NATIONAL LABORATORY \\ P.O. Box 2008 \\ Oak Ridge, Tennessee 37831-6285 \\ managed by \\ UT-BATTELLE, LLC \\ for the \\ U.S. DEPARTMENT OF ENERGY \\ under contract DE-AC05-00OR22725
}

*Mr. Hopper is solely responsible for the content of this report, which does not necessarily reflect the positions or judgments of Oak Ridge National Laboratory or the US Department of Energy, Office of Nuclear Safety. 



\section{CONTENTS}

Page

LIST OF TABLES

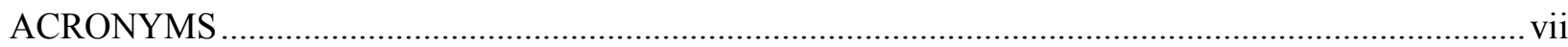

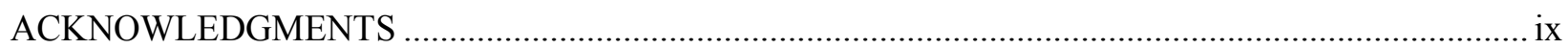

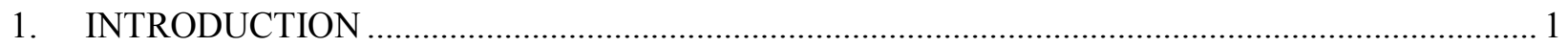

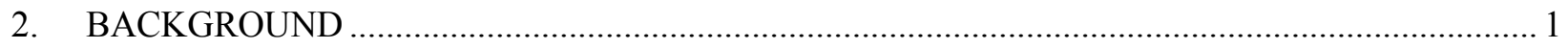

2.1 DOMESTIC VOLUNTARY CONSENSUS STANDARDS DEVELOPMENT

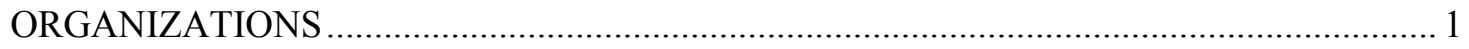

2.2 INTERNATIONAL VOLUNTARY CONSENSUS STANDARDS DEVELOPMENT

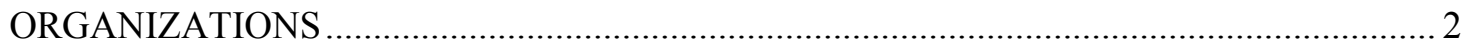

3. STRUCTURE AND OPERATION OF STANDARDS DEVELOPMENT ORGANIZATIONS ........ 3

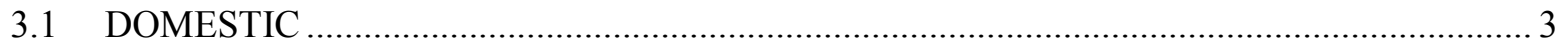

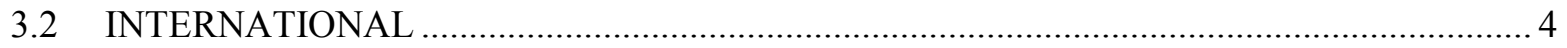

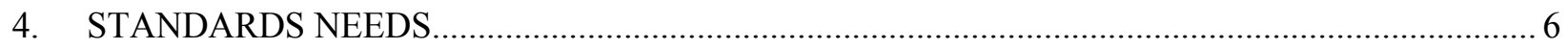

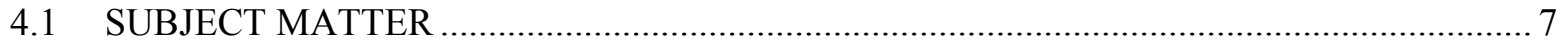

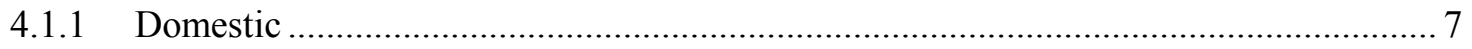

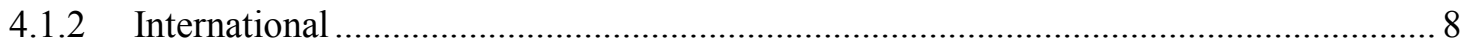

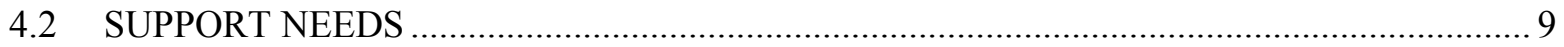

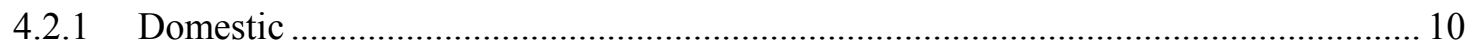

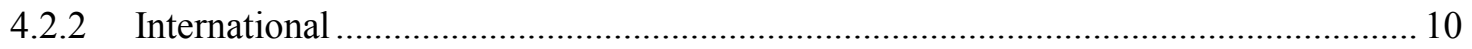

4.2.3 Summary of Standards Support Needs .................................................................. 11

APPENDIX A. STEPS IN THE DEVELOPMENT OF AN AMERICAN NUCLEAR SOCIETY STANDARD. A-1

APPENDIX B. STAGES OF AN INTERNATIONAL ORGANIZATION FOR STANDARDIZATION STANDARD DEVELOPMENT RESULTING IN DRAFT INTERNATIONAL STANDARD, FINAL DRAFT INTERNATIONAL STANDARD, AND APPROVED ISO STANDARD

APPENDIX C. STRUCTURE AND MANAGEMENT OF INTERNATIONAL ORGANIZATION FOR STANDARDIZATION TECHNICAL COMMITTEE 85 SUBCOMMITTEE AND WORKING GROUP MEMBERSHIP. 



\section{LIST OF TABLES}

Table

Page

$1 \quad$ ISO TC85 and NTAG organization structures ............................................................. 4

2 Number of SMEs from the 17 P-Member countries who participated in the

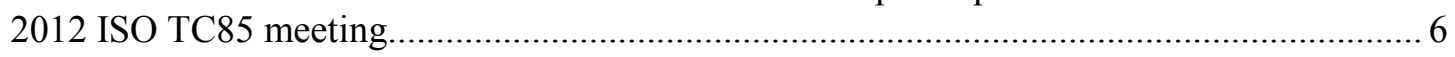





\section{ACRONYMS}

$\begin{array}{ll}\text { ANS } & \text { American Nuclear Society } \\ \text { ANSI } & \text { American National Standards Institute } \\ \text { ASME } & \text { American Society of Mechanical Engineers } \\ \text { ASTM } & \text { ASTM International (previously American Society of Testing and Materials) } \\ \text { AWS } & \text { American Welding Society } \\ \text { CC } & \text { consensus committee } \\ \text { CTG } & \text { Concrete Task Group } \\ \text { DOE } & \text { US Department of Energy } \\ \text { HPS } & \text { Health Physics Society } \\ \text { IEC } & \text { International Electrotechnical Commission } \\ \text { IEEE } & \text { Institute of Electrical and Electronics Engineers } \\ \text { INMM } & \text { Institute of Nuclear Materials Management } \\ \text { ISO } & \text { International Organization for Standardization } \\ \text { NESCC } & \text { Nuclear Energy Standards Coordination Collaborative } \\ \text { NFPA } & \text { National Fire Protection Association } \\ \text { NGO } & \text { nongovernmental organization } \\ \text { NRC } & \text { Nuclear Regulatory Commission } \\ \text { NTAG } & \text { Nuclear Technical Advisory Group } \\ \text { PINS } & \text { Project Initiation Notification System } \\ \text { SB } & \text { standards board } \\ \text { SC } & \text { subcommittee } \\ \text { SDO } & \text { standards development organization } \\ \text { SME } & \text { subject matter expert } \\ \text { TC } & \text { technical committee } \\ \text { TC85 } & \text { ISO Technical Committee 85, "Nuclear energy, nuclear technologies, and } \\ \text { WG } & \text { radiological protection" } \\ & \text { working group } \\ & \end{array}$





\section{ACKNOWLEDGMENTS}

The author wishes to acknowledge the US Department of Energy, Office of Nuclear Safety, for its support of this work and the staff at the Oak Ridge National Laboratory, specifically Dr. R. Michael Westfall and Mr. Douglas G. Bowen for their technical reviews, Ms. Deborah J. Weaver for document preparation, and Ms. Priscilla P. Henson for editorial services. 



\section{INTRODUCTION}

This report introduces the reader to the domestic and international standards development organizations (SDOs) and their structures and operations. It also identifies some of the support and subject matter needs for the development of standards on the subject of nuclear energy. The support needs are described with regard to organizational structure and subject-matter-expert (SME) participation that is required for producing voluntary consensus standards. The subject matter needs are described with regard to growing technologies and objectives that approach the boundaries of existing standards; implementation of knowledge; and safety of people, facilities, and the environment.

The development of voluntary consensus standards has been initiated by a group of multiple stakeholders that broadly recognizes the need for one or more standards. Voluntary consensus SDOs have professional participation by individuals who generally receive limited or no financial or infrastructural support, which is in contrast to the approach for nonconsensus or limited-consensus industry, agency, and government guidance, standards, regulations, or laws. Generally, nonconsensus standards exist as the result of an industry- or government-focused infrastructural and financial support system that addresses a specific subject matter need (e.g., the compatibility of discharge hoses on a specific brand of clothes washing machines; the content and format of the US Department of Energy [DOE]/Nuclear Regulatory Commission [NRC] Form 741, "Nuclear Material Transaction Reports").

\section{BACKGROUND}

\subsection{DOMESTIC VOLUNTARY CONSENSUS STANDARDS DEVELOPMENT ORGANIZATIONS}

Within the United States domestic consensus standards are generally developed by SDOs that meet the essential requirements* of the American National Standards Institute (ANSI) for accreditation. Examples of ANSI SDOs that contribute to nuclear energy standards include the following:

- American Nuclear Society (ANS)

- American Welding Society (AWS)

- ASTM International (ASTM)

- American Society of Mechanical Engineers (ASME)

- Health Physics Society (HPS)

- Institute of Electrical and Electronics Engineers (IEEE)

- Institute of Nuclear Materials Management (INMM)

- National Fire Protection Association (NFPA)

There are other non-ANSI accrediting organizations within the United States (e.g., National Cooperation for Laboratory Accreditation). However, ANSI is the only congressionally authorized consensusaccrediting organization to represent the United States in the development of international consensus

*See http://publicaa.ansi.org/sites/apdl/Documents/Standards\%20Activities/American\%20National\%20Standards/ Procedures,\%20Guides,\%20and\%20Forms/2013_ANSI_Essential_Requirements.pdf. 
standards on nuclear energy. International US participation is managed by ANSI via its Nuclear Technical Advisory Group (NTAG), ${ }^{*}$ which is composed of various SDO experts within the United States.

The ANSI accreditation process certifies each ANSI SDO policy and procedure to ensure that there is a balance of interests represented throughout the approval process of a developed standard. This balance of interest requires, as a minimum, that representatives from the categories of producers, users, and generalinterest persons/groups participate in the standards development, approval, and publication process. As suggested by ANSI, ${ }^{\dagger}$ additional interest categories should be considered such as consumer, directly affected public, distributor and retailer, industrial/commercial, insurance, labor, manufacturer, professional society, regulatory agency, testing laboratory, and/or trade association.

Currently ANSI has nearly 200 separate certified SDOs. In addition to the current and historic role of ANSI, it has also led to the evolution of a new organization under its auspices. The new organization, called the Nuclear Energy Standards Coordination Collaborative (NESCC), is a joint initiative of ANSI and the National Institute of Standards and Technology (NIST). NESCC is not an SDO. Instead, it is intended to create a highly inclusive, collaborative forum with participation from a range of perspectives that is not disproportionately dependent upon any single interest, organization, or stakeholder group for identifying domestic standard needs.

The mission of the recently formed (circa 2009) NESCC is ". . . to identify and respond to the current needs of the nuclear industry." In that role NESCC has endeavored to encourage all stakeholders, including appropriate SDOs, to participate in the identification of nuclear industry standards needs. Approximately 6 ANSI SDOs, 4 government agencies, 5 NGOs, 1 university, and 24 consulting or commercial organizations are participating in NESCC. By consolidating information development and sharing, the organization seeks to avoid duplication of effort by SDOs.

The identification of domestic nuclear energy standards support and subject matter needs is drawn from ANS and other standards SDO's work and NESCC. An example of an SDO contribution to identifying domestic standard needs is the report Concrete Codes and Standards for Nuclear Power Plants:

Recommendations for Future Development. ${ }^{\S}$

\subsection{INTERNATIONAL VOLUNTARY CONSENSUS STANDARDS DEVELOPMENT ORGANIZATIONS}

The two main international voluntary consensus SDOs engaged in the development of nuclear energy consensus standards are the International Electrotechnical Commission (IEC) and the International Organization for Standardization (ISO), both headquartered in Geneva, Switzerland. As the name implies, IEC develops standards related to electromagnetic systems, whereas ISO develops ones related to a myriad of subjects, only one of which is nuclear energy, nuclear technologies, and radiological protection under the auspices of ISO Technical Committee 85, "Nuclear energy, nuclear technologies, and radiological protection" (TC85). Currently ISO maintains about 200 individual SDOs.

Somewhat similar to ANSI's essential requirements, ISO requires "Participating (P)" full member countries to be represented by their SMEs through the P-Member national standards body (e.g., ANSI).

\footnotetext{
*See http://www.astm.org/COMMIT/TC85_Operating.pdf.

${ }^{\dagger}$ See http://publicaa.ansi.org/sites/apdl/Documents/Standards\%20Activities/American\%20National\%20Standards/ Procedures,\%20Guides,\%20and\%20Forms/2013_ANSI_Essential_Requirements.pdf.

${ }^{\ddagger}$ See http://www.ansi.org/standards_activities/standards_boards_panels/nescc/overview.aspx?menuid=3\#Document.

${ }^{\S}$ See http://publicaa.ansi.org/sites/apdl/Documents/Meetings\%20and\%20Events/NESCC/NESCC_2011/

NESCC_Final_Report_of_the_Concrete_Task_Group.pdf.
} 
Those SMEs not only come from the relevant industry, but also from consumer associations, academia, nongovernmental organizations (NGOs), government, and other interested parties. As previously mentioned, the national standards body representing the United States in ISO standards development is ANSI. ANSI's SMEs include experts from both industry and government. ANSI's SDOs maintain an "open door" for and solicit participation from interested parties. As in the development of ANSI standards, participation of US SMEs in the ISO TC85 standards development process is a voluntary effort that is generally minimally underwritten by industry or government.

\section{STRUCTURE AND OPERATION OF STANDARDS DEVELOPMENT ORGANIZATIONS}

\subsection{DOMESTIC}

As previously described, the domestic US standards relevant to nuclear energy are developed by SDOs that are accredited by ANSI. Generally the need for a specific standard is identified by industry, government, or NGOs. The identified need is shared with the most relevant SDO management, or standards board (SB), for consideration. The SDO SB then suggests that its relevant consensus committee (CC) investigate the availability of SMEs and the level of interest in developing the suggested standard. The CC is required to have an ANSI-certified balance of interest (i.e., at least producers, users, and general interest persons/groups as members). Generally CCs have a majority of members with technical competence in the subject matter of the standards under its purview and development. This CC composition ensures that the development of a standard is judged to be needed and occurs within the appropriate community of SMEs. If the $\mathrm{CC}$ endorses the proposal to develop a suggested standard, the suggestion will be passed to the relevant SDO CC subject matter subcommittee (SC). The SC is composed of SMEs in the general subject matter of the $\mathrm{CC}$ and is not required to maintain a balance of interest. If the SC concurs with the need for the suggested standard, it identifies highly specific SMEs to prepare an ANSI Project Initiation Notification System (PINS) form for national approval. Subsequent to sequential approval of the PINS by the SC, CC, SB, ANSI, and public, a working group (WG) of highly specific SMEs is constituted to draft the suggested standard. Once the suggested standard has been reviewed, reviewer comments have been received and addressed, and sequential approval is complete, the standard is published as an ANSI standard. The development and approval process for an ANSI standard for ANS is shown in Appendix A.

A large contingent of SMEs is necessary to produce and manage the development of standards, which must also be periodically reviewed and/or revised. As an example, ANS currently has a SB of 13 professionals, 4 CCs of 86 professionals, 16 SCs of 122 professionals, and about 120 WGs of about 1333 SME professionals. Using this total number of professionals per SDO as a model and considering only the seven SDOs previously identified yields about 11,000 professionals engaged in the development and/or maintenance of nuclear energy standards. Given the maturity of SDOs such as ASME, ASTM, AWS, HPS, NFPA, and IEEE and their broad impact on the nuclear industry, it is likely that the estimated 11,000 professionals is a significant underestimate of the total number actually involved in standards development.

Government organizations or agencies (e.g., DOE, NRC, US Department of Transportation) generally participate or liaison with the ANSI SDOs regarding the development or endorsement of ANSI standards relevant to their regulated domains.

An additional desirable function for NESCC domestic standards would be coordination with the ANSI NTAG organization, which is responsible for participating in the development, review, commenting, and balloting on ISO standards. The ANSI NTAG organization is a mirror of ISO TC85, as shown in Table 1. 
Table 1. ISO TC85 and NTAG organization structures

\begin{tabular}{ll}
\hline \multicolumn{1}{c}{ ISO TC85 structure } & \multicolumn{1}{c}{ NTAG structure* } \\
\hline ISO & ANSI/ASTM \\
TC85 Chairman & NTAG \\
TC85 Chairman Advisory Group & NTAG Executive Committee \\
TC85/SC Chairs & NTAG Overall Advisors for SCs \\
TC85/SC/WG Conveners & NTAG Deputy Overall Advisors for WGs \\
Participating Country Subject Matter Experts & NTAG Subject Matter Technical Experts \\
* See http://www.astm.org/COMMIT/TC85_Operating.pdf.
\end{tabular}

\subsection{INTERNATIONAL}

ISO Headquarters functions somewhat like ANSI in that it manages the final international P-Member reviews, comments, comment resolution, and approval of ISO standards with the assistance of the relevant technical committee (TC), SC, and WG. It monitors the participation of member countries to determine qualifications for continued membership. ISO TC85 functions somewhat like the ANS SB in that it manages its SCs, which in turn manage the WGs that draft ISO standards. The ISO TC85 SCs function somewhat like an ANS CC except that the balance of interest is provided by delegates from the ISO P-Members' producers, users, and general interest persons/groups.

The scopes of ISO TC85 standards are limited, as implied by the titles of the SCs:

- SC2, "Radiological protection," has 13 active WGs

- SC5, "Nuclear fuel cycle," has 5 active WGs

- SC6, "Reactor technology," has 2 active and 1 evolving WG

Similar to SDOs accredited by ANSI, ISO includes various other TCs that have direct relevance to the nuclear industry:

- TC5, "Ferrous metal pipes and metallic fittings"

- TC11, "Boilers and pressure vessels"

- TC21, "Equipment for fire protection and fire fighting"

- TC71, "Concrete, reinforced concrete and pre-stressed concrete"

- TC92, "Fire safety"

- TC98, "Bases for design of structures";

- TC135, "Non-destructive testing"

- numerous other TCs 
TC85 is composed of

- a Nuclear Safety Advisory Group of approximately 6 professionals

- Ad Hoc Group 1 on management systems and conformity assessment of approximately 13 professionals

- a Chairman Advisory Group of approximately 14 professionals

- WG 1 on terminology, definitions, units, and symbols of approximately 22 professionals

- WG 3 on dosimetry for radiation processing of 11 professionals

- $\operatorname{SCs} 2,5$, and 6 with approximately 130 international meeting professionals

WGs 1 and 3 function like US domestic standards development WGs but under the auspices of TC85. TC85 functions much like the ANS SB. It oversees the conduct and coordination of ISO TC85 SC activities. The ISO TC85 SC's function is to coordinate and manage the activities and products of the ISO TC85 SC WGs. ISO does not have an organization that functions as a CC. That is the role of the ISO WG members. Standards are drafted and finalized by the consensus of the respective WGs and ultimately approved or disapproved by the P-Members of ISO. Further details about the development of ISO standards and the management and structure of ISO TC85 SCs and WGs are provided in Appendices B and $\mathrm{C}$, respectively.

About 130 P-Member professionals participate and/or represent the 24 P-Member countries as delegates or heads of delegations at international meetings. In each of the P-Member countries, three to seven SME professionals are engaged in the review, commenting, balloting, and approval for each ISO TC85 SC5 WG activity. That is to say, of the combined 17 WGs, approximately 204 professionals in each of the 24 P-Member countries are engaged in ISO TC85 SC5 WG standards development, resulting in about 2000 professionals worldwide - not unlike the total of SME professionals involved in the ANS standards work.

Table 2 provides a tabulation of the number of SMEs from the 17 P-Member countries who participated in the 2012 ISO TC85 meeting. Out of all the international delegates attending that meeting, the United States had 6 out of 109 delegates to SC2, 7 out of the 71 delegates to SC5, and 2 out of the 19 delegates to SC6. 
Table 2. Number of SMEs from the 17 P-Member countries who participated in the 2012 ISO TC85 meeting

\begin{tabular}{lcc}
\hline P-Member country & P-Member national standards body & $\begin{array}{c}\text { Number of } \\
\text { delegates }\end{array}$ \\
\hline France & Association Française de Normalisation & 70 \\
United Kingdom & British Standards Institute & 17 \\
Russian Federation & Federal Agency on Technical Regulating and Metrology & 16 \\
United States of & ANSI & 14 \\
America & & \\
Japan & Japanese Industrial Standards Committee & 13 \\
Germany & Deutsches Institut für Normung & 11 \\
Korea & Korean Agency for Technology and Standards & 11 \\
Canada & Standards Council of Canada & 10 \\
Italy & Ente Nazionale Italiano di Unificazione & 7 \\
China & Standardization Administration of China & 4 \\
Spain & Asociación Española de Normalización y Certificación & 4 \\
Sweden & Swedish Standards Institute & 4 \\
Switzerland & Swiss Association for Standardization & 4 \\
Argentina & Instituto Argentino de Normalización y Certificación & 2 \\
Austria & Austrian Standards Institute & 2 \\
India & Bureau of Indian Standards & 2 \\
Belgium & Bureau de Normalisation & 1 \\
\hline
\end{tabular}

\section{STANDARDS NEEDS}

As previously stated, consensus standards require the participation of producers, users, and general interest persons/groups, and a majority of those participants is necessary to initiate the development of such a standard. Most participants generally have mutual interests, but they also have strong tendencies for their own self-interests. The self-interests are usually economically driven ones to maximize profit in trade and minimize losses in the market share or liabilities. The result of those drivers is a cautious industry trying to avoid costs from (1) development of standards that have limited obvious economic returns and (2) creation of standards that will possibly impact the status quo of their industries' production. Conversely, the mutual and self-interests of the participants at play in the development of standards can stimulate trade and safety. The participation by general interest persons/groups in the development of standards can provide a "safe harbor" for users and producers.

Consensus standards are backed by the credentials of expert contributors and consensus builders while also representing a broad balance of interests. Standardization for usability, trade, and safety has positive outcomes for all parties. To justify the costs of developing standards, however, a long view of the results needs to be taken because support for SMEs' contribution to the standards process is costly. It is usually difficult to identify standards needs in the long term (e.g., 5 to 10 years later). Short-term standards needs are usually easily identifiable, though, because they result from an immediate product need, application or trade need, catastrophe, or regulatory oversight expectation. Regardless of the drivers, there is an economic impact, positive or negative, from the development and deployment of standards both in terms of subject matter needs and human resources required. 


\subsection{SUBJECT MATTER}

Subject matter needs are variable depending upon the intended domestic or international application of the standards. Where international trade and safety are important, the producer and user of the goods need a common understanding of the product's function, quality, and safety.

\subsubsection{Domestic}

Within the United States, the focus of standards subject matter needs has become somewhat dispersed. In the early days of the nuclear industry, much reliance was necessarily placed upon existing standards for boiler making, turbine designs, chemical processes, etc. With the advent of ANS, the development of nuclear standards became common and migrated into the subject matters of safety systems, design criteria, and others. Following a surge in the nuclear industry in the 1960s and 1970s, there was a decline in public support for it. The recent resurgence of US interest in energy independence and the country's consideration of small modular reactors and irradiated fuel management have generated a new interest in standards to address these subjects.

Recently NESCC identified some standards needs among the ANSI SDOs. An example is found in a recent NESCC Concrete Task Group (CTG) report.* Membership on the CTG was open (i.e., no attempt was made to limit the membership), and efforts were made to include representatives from SDOs and the construction industry who are involved in new nuclear power plant construction. The needs identified include addressing the following:

- high-strength reinforcing steel

- concrete radiation shielding

- concrete durability

- performance-based design

- ultra-high-performance concretes

- use of lapped splices in regions of low biaxial tension

- temperature loading on concrete

- other needs such as modular construction versus field manufacturing, integration of updated codes and standards into design software, updating of construction codes, integration of the concrete strength design provisions of American Concrete Institute (ACI) 349 into the ACI 359/ASME Division 2 Concrete Containment Code

ASME has identified needs and is doing research on the following subjects:

- allowable stresses on operating conditions

- intermediate heat exchangers

- creep and creep-fatigue crack growth on structural discontinuities and welds

- advanced nondestructive evaluation methods for high-temperature gas-cooled reactors

*See http://publicaa.ansi.org/sites/apdl/Documents/Meetings\%20and\%20Events/NESCC/NESCC_2011/NESCC_Final_Rep ort_of_the_Concrete_Task_Group.pdf. 
ANS has identified subject matters to focus their standards efforts in the following areas:

- high-temperature gas-cooled reactors

- small modular reactors

- irradiated fuel management

- Fukushima-related failures

- collaboration with ASME on development of risk/probabilistic risk assessment standards for levels 1-3

AWS has identified standards changes to address the following:

- avoiding senseless requalification of welding procedures

- aligning two or more SDO standards content to be complementary

- making repair decisions based on fitness-for-service assessments

- waveform-based power sources

- phased-array ultrasonic inspection

- digital X-ray imaging technology

- visual inspection

- personnel certification

The American Institute of Steel Construction has identified potential standards needs for steel plate and concrete modular composite construction that include the following:

- design requirements

- analysis requirements

- designs for tension, compression, out-of-plane flexure, in-plane and out-of-plane shear, combined forces, and impactive and impulsive loads

The identification of other needs is still under way within NESCC and includes gap analyses by various ANSI SDOs.

\subsubsection{International}

Internationally ISO TC85 has a business plan* that describes the intended future standards products that are judged to be needed in the short and medium term for the nuclear industry. They include the following:

- proposition of a process for harmonization of national standards and inclusion of best national practices in international ISO standards

- proposition of collaboration with relevant international organizations such as the International Atomic Energy Agency, the Organization for Economic Cooperation and Development/Nuclear Energy Agency, and the World Association of Nuclear Operators to increase the efficiency of this process

\footnotetext{
*See http://isotc.iso.org/livelink/livelink/fetch/2000/2122/687806/ISO_TC_085_Nuclear_energy_.pdf?nodeid=689169\&ve rnum $=-2$.
} 
and identify areas in which national regulations are an obstacle to the harmonization of standards or codes

- development of terminology, definitions, units, and symbols for consistency among ISO TC85 standards development

- dosimetry for radiation processing

- monitoring of radon in the environment and buildings

- patient safety in radiotherapy processes

- monitoring of nuclear facilities' airborne and liquid releases to the environment

- waste management and monitoring of solid releases from nuclear facilities

- decontamination, decommissioning, and demolition techniques and service for nuclear facilities

- analysis and measurements in support of safe operation of nuclear power plants and research reactors and with decay heat calculations in support of reactor safety

- safe and efficient operation of research reactors and with services from research reactors

- new technologies of low-enriched-uranium fuel for research reactors

- consideration of commercial isotope production in research reactors with the objective of improving availability of isotope production for use in medicine, research, and industry.

\subsection{SUPPORT NEEDS}

In the 1960s and 1970s, the nuclear industry throughout the world was growing. Government and industry were willing to support personnel time, travel, and standards development to further the progress of the industry. Following various notorious events (e.g., Three Mile Island, the Chernobyl disaster, and most recently Fukushima), the public and government became focused on proposing regulations in an attempt to eliminate hazards rather than to control them and keep their possible consequences to acceptable risk levels. The public now expects regulations to limit the frequency of such extreme events to close to once in a million years and applies the same standards to exceedingly infrequent and low-consequence events such as industrial nuclear criticality accidents. These notorious events, public concerns, and regulatory expectations have exerted increasing pressure on the nuclear industry, especially in the United States and Great Britain, to exercise more caution regarding its business decisions, thereby retarding or preventing further progress of the industry and its needed standards development.

Within ANS standards activities, personnel participation has significantly waned, resulting in no maintenance of many existing standards and slower or no development of new ones. ISO TC85 has also seen a decline in international participation in its standards development process. 


\subsubsection{Domestic}

A recent presentation to NESCC (November 29, 2012)* concerning US standards prioritization efforts was developed by a task group from ANS to identify standards needs and obstacles to addressing them. That presentation included national standards organizational/management objectives including the following:

- bringing focus/working smarter

- helping the federal government's nuclear sectors achieve goals

- loading resources

- doing what's needed first

- wisely using limited resources

- identifying

- resources (government: NIST, NRC, DOE; industry: AEs, NSSS, operating entities; SDOs)

- customer

- priority

- criteria

- going back to National Technology Transfer and Advancement Act/Office of Management and Budget A-119 reasons supporting standards

It is recognized that organizations can prioritize their objectives as they want, if they are funded. NESCC can reprioritize, comment, or suggest guidance but cannot direct work. The NESCC task group is continuing to perform a gap analysis on the existing standards and to identify further standards needs.

The obstacles to addressing the above objectives and standards define the support needs for the United States. It is recognized that

- non-SDOs worry new standards will open areas already "solved";

- manufacturing trade organizations such as the Cooling Tower Institute are generally not accredited by ANSI and typically not SDOs;

- SDOs such as ANS, ASME, IEEE, ACHE, ASQ, and ASTM have their own priorities; and

- priorities are skewed toward current crises and balanced by strategic nuclear vision.

\subsubsection{International}

ISO TC85 recognizes several international factors that make the production of timely, needed standards difficult. Insufficient participation is the key factor affecting ISO TC85 efficiency.

Several factors contributing to this lack of participation have to be discussed and managed, including the following:

\footnotetext{
*See NESCC 12-087, presentation from the National Standards Priority List TG to the November 29, 2012 NESCC Mtg at $\mathrm{http}: / /$ publicaa.ansi.org/sites/apdl/Documents/Forms/AllItems.aspx?RootFolder=\% $2 \mathrm{fsites} \% 2 \mathrm{fapdl} \% 2 \mathrm{fDocuments} \% 2 \mathrm{fMeetings} \%$ 20 and $\% 20$ Events $\% 2$ f2009\%20NESCC $\% 2$ fNESCC $\% 20$ Meeting $\% 20 \% 2 \mathrm{~d} \% 20$ November $\% 2029 \% 2 \mathrm{c} \% 202012 \&$ View $=\% 7 \mathrm{~b} 21 \mathrm{C} 60$ $355 \% 2 \mathrm{dAB} 17 \% 2 \mathrm{~d} 4 \mathrm{CD} 7 \% 2 \mathrm{dA} 090 \% 2 \mathrm{dBABEEC} 5 \mathrm{D} 7 \mathrm{C} 60 \% 7 \mathrm{~d}$.
} 
- Lack of expertise: In many countries the present rebirth of the nuclear industry is occurring at the same time as the retirement of many experts. In such a context, a priority must be to identify and introduce younger experts to the standardization process.

- Meetings and other standards production costs: Many organizations are more and more reluctant to finance expensive expert meetings. Electronic exchanges, virtual meetings, and perhaps regional meetings or ISO meetings colocated with other professional meetings of the nuclear industry have to be developed.

- Incomplete transition from national markets, regulations, and standards toward a global international market with unresolved harmonization issues: A systematic harmonization of codes, standards, and regulations is not a realistic aim for the immediate market of new reactors, but pragmatic steps will have to be taken, and ISO can offer a legitimate international framework for some of them.

\subsubsection{Summary of Standards Support Needs}

Standards are proposed, developed, and produced by SMEs with the support of industry and government organizations. The voluntary consensus standards development process is, as its name implies, a voluntary effort. The problem in today's competitive market, impacted by global economic uncertainty, is that the voluntary participation is shifting from a collaborative industry and SME effort to a nearly SME-only one. This shift places a financial and/or time burden on the SMEs to the point that they are purposely withdrawing from the standards development process, both domestically and internationally. The standards development process desperately needs participation from more and younger SMEs. This need could be addressed by

1. stimulating industry and government to support SME participation,

2. identifying more industry and government SMEs who should take an interest in standards development, and

3. prioritizing and coordinating the development of standards.

Item 1 can only be accomplished by shifting the priorities of industry and government by reminding them of the benefits of standardization, which include, but are limited to, the following:

- $\quad$ simplifying guidance

- promoting safety

- certifying quality

- promoting interchangeability through standardization

- providing confidence

- controlling costs

- developing common specifications (for contracts, etc.)

- helping uninformed users

- fostering innovation and sharing

- helping fairly manage diversity

- $\quad$ spreading knowledge 
Item 2 could be addressed by those organizations with a central knowledge of the nuclear industry and government players in it. A more comprehensive network of SMEs needs to be developed within the United States and internationally. Typically the US regulators (i.e., DOE and NRC) and SDOs are in the best position and have sufficient information about the US nuclear industry to identify points of contacts or other SMEs who might participate in the standards development processes. Such participation would necessarily require some industry or government support because many of the standards activities frequently require substantial SME time or effort and occasional travel.

Item 3 can only be accomplished with the cooperation of industry, government, and interested parties. Clearly a national US push to coordinate standards efforts is needed. The formation of NESCC was a good start toward coordinating the numerous SDOs to address prioritized needs. Likewise, ISO TC85 has the organizational structure to coordinate the international standards development process, but it is dependent upon its P-Members comprehensively engaging in the ISO standards process, which won't happen until the P-Members satisfactorily address items 1-3. 
APPENDIX A. STEPS IN THE DEVELOPMENT OF AN AMERICAN NUCLEAR SOCIETY STANDARD 



\section{APPENDIX A. STEPS IN THE DEVELOPMENT OF AN \\ AMERICAN NUCLEAR SOCIETY STANDARD*}
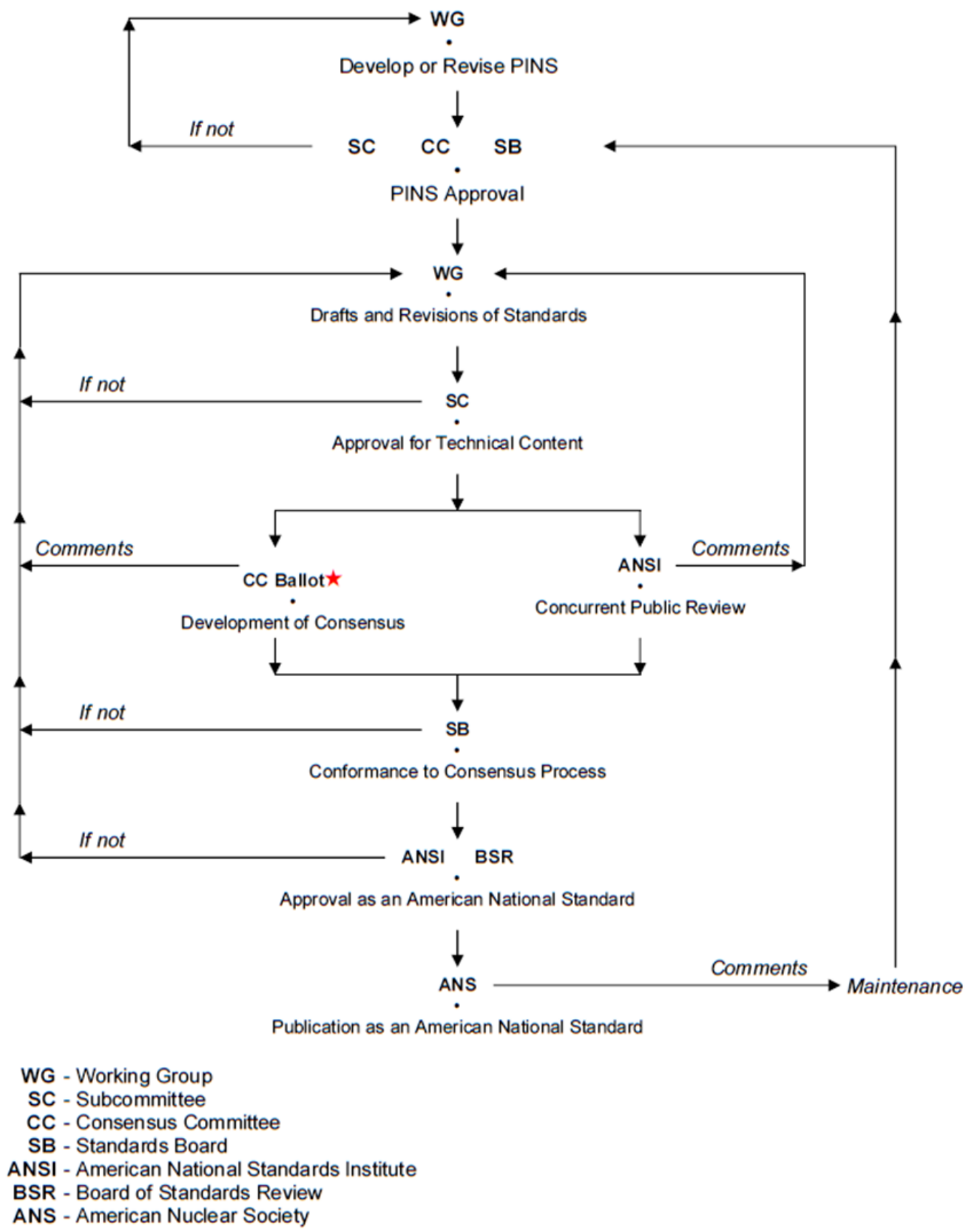

ネ If a decision is made to issue a draft for trial use and application (TUPA). an additional CC ballot (w/o public review) as well as SB approval would be required. If approved by the CC \& SB, the draft would be published and available for purchase. Once the trial use period was completed, the working group would review the comments and determine the appropriate action. If seeking approval of the draft as an American National Standard, the draft would be revised to incorporate comments and continue to follow the process noted in the flow chart to gain ANSI certification.

${ }^{*}$ See http://www.new.ans.org/standards/resources/downloads/docs/comactivitiesreport2011.pdf, page 4. 

APPENDIX B. STAGES OF AN INTERNATIONAL ORGANIZATION FOR STANDARDIZATION STANDARD DEVELOPMENT RESULTING IN DRAFT INTERNATIONAL STANDARD, FINAL DRAFT INTERNATIONAL STANDARD, AND APPROVED ISO STANDARD 



\section{APPENDIX B. STAGES OF AN INTERNATIONAL ORGANIZATION FOR STANDARDIZATION STANDARD DEVELOPMENT RESULTING IN DRAFT INTERNATIONAL STANDARD, FINAL DRAFT INTERNATIONAL STANDARD, AND APPROVED ISO STANDARD*}

\begin{tabular}{|c|c|c|c|c|c|c|c|}
\hline \multirow[t]{3}{*}{ STAGE } & \multicolumn{7}{|l|}{ SUBSTAGE } \\
\hline & \multirow[b]{2}{*}{$\begin{array}{l}00 \\
\text { Registration }\end{array}$} & \multirow[b]{2}{*}{$\begin{array}{l}20 \\
\text { Start of main } \\
\text { action }\end{array}$} & \multirow[b]{2}{*}{$\begin{array}{l}60 \\
\text { Completion } \\
\text { of main } \\
\text { action }\end{array}$} & \multicolumn{4}{|c|}{$\begin{array}{l}90 \\
\text { Decision Substages }\end{array}$} \\
\hline & & & & $\begin{array}{l}92 \\
\text { Repeat an } \\
\text { earlier phase }\end{array}$ & $\begin{array}{l}93 \\
\text { Repeat } \\
\text { current phase }\end{array}$ & $\begin{array}{l}98 \\
\text { Abandon }\end{array}$ & $\begin{array}{l}99 \\
\text { Proceed }\end{array}$ \\
\hline $\begin{array}{l}00 \\
\text { Preliminary } \\
\text { stage }\end{array}$ & $\begin{array}{l}00.00 \\
\text { Proposal for } \\
\text { new project } \\
\text { received }\end{array}$ & $\begin{array}{c}00.20 \\
\text { Proposal for } \\
\text { new project } \\
\text { under review }\end{array}$ & $\begin{array}{l}00.60 \\
\text { Close of } \\
\text { review }\end{array}$ & & & $\begin{array}{l}00.98 \\
\text { Proposal for } \\
\text { new project } \\
\text { abandoned }\end{array}$ & $\begin{array}{c}00.99 \\
\text { Approval to } \\
\text { ballot proposal } \\
\text { for new project }\end{array}$ \\
\hline $\begin{array}{l}10 \\
\text { Proposal } \\
\text { stage }\end{array}$ & $\begin{array}{c}10.00 \\
\text { Proposal for } \\
\text { new project } \\
\text { registered }\end{array}$ & $\begin{array}{c}10.20 \\
\text { New project } \\
\text { ballot initiated }\end{array}$ & $\begin{array}{l}10.60 \\
\text { Close of } \\
\text { voting }\end{array}$ & $\begin{array}{l}10.92 \\
\text { Proposal } \\
\text { returned to } \\
\text { submitter for } \\
\text { further } \\
\text { definition }\end{array}$ & & $\begin{array}{c}10.98 \\
\text { New project } \\
\text { rejected }\end{array}$ & $\begin{array}{c}10.99 \\
\text { New project } \\
\text { approved }\end{array}$ \\
\hline $\begin{array}{l}20 \\
\text { Preparatory } \\
\text { stage }\end{array}$ & $\begin{array}{l}20.00 \\
\text { New project } \\
\text { registered in } \\
\text { TC/SC work } \\
\text { programme }\end{array}$ & $\begin{array}{l}20.20 \\
\text { Working draft } \\
\text { (WD) study } \\
\text { initiated }\end{array}$ & $\begin{array}{l}20.60 \\
\text { Close of } \\
\text { comment } \\
\text { period }\end{array}$ & & & $\begin{array}{l}20.98 \\
\text { Project } \\
\text { deleted }\end{array}$ & $\begin{array}{c}20.99 \\
\text { WD approved } \\
\text { for registration } \\
\text { as CD }\end{array}$ \\
\hline $\begin{array}{l}30 \\
\text { Committee } \\
\text { stage }\end{array}$ & $\begin{array}{c}30.00 \\
\text { Committee } \\
\text { draft }(C D) \\
\text { registered }\end{array}$ & $\begin{array}{c}30.20 \\
C D \\
\text { study/ballot } \\
\text { initiated }\end{array}$ & $\begin{array}{l}30.60 \\
\text { Close of } \\
\text { voting/ } \\
\text { comment } \\
\text { period }\end{array}$ & $\begin{array}{l}30.92 \\
\text { CD referred } \\
\text { back to } \\
\text { Working } \\
\text { Group }\end{array}$ & & $\begin{array}{l}30.98 \\
\text { Project } \\
\text { deleted }\end{array}$ & $\begin{array}{c}30.99 \\
\text { CD approved } \\
\text { for registration } \\
\text { as DIS }\end{array}$ \\
\hline $\begin{array}{l}40 \\
\text { Enquiry } \\
\text { stage }\end{array}$ & $\begin{array}{l}40.00 \\
\text { DIS registered }\end{array}$ & $\begin{array}{l}40.20 \\
\text { DIS ballot } \\
\text { initiated: } 5 \\
\text { months }\end{array}$ & $\begin{array}{l}40.60 \\
\text { Close of } \\
\text { voting }\end{array}$ & $\begin{array}{c}40.92 \\
\text { Full report } \\
\text { circulated: } \\
\text { DIS referred } \\
\text { back to TC or } \\
\text { SC }\end{array}$ & $\begin{array}{l}40.93 \\
\text { Full report } \\
\text { circulated: } \\
\text { decision for } \\
\text { new DIS } \\
\text { ballot }\end{array}$ & $\begin{array}{l}40.98 \\
\text { Project } \\
\text { deleted }\end{array}$ & $\begin{array}{l}40.99 \\
\text { Full report } \\
\text { circulated: DIS } \\
\text { approved for } \\
\text { registration as } \\
\text { FDIS }\end{array}$ \\
\hline $\begin{array}{l}50 \\
\text { Approval } \\
\text { stage }\end{array}$ & $\begin{array}{c}50.00 \\
\text { FDIS } \\
\text { registered for } \\
\text { formal } \\
\text { approval }\end{array}$ & $\begin{array}{l}50.20 \\
\text { FDIS ballot } \\
\text { initiated: } 2 \\
\text { months. } \\
\text { Proof sent to } \\
\text { secretariat }\end{array}$ & $\begin{array}{l}50.60 \\
\text { Close of } \\
\text { voting. } \\
\text { Proof } \\
\text { returned by } \\
\text { secretariat }\end{array}$ & $\begin{array}{l}50.92 \\
\text { FDIS referred } \\
\text { back to TC or } \\
\text { SC }\end{array}$ & & $\begin{array}{l}50.98 \\
\text { Project } \\
\text { deleted }\end{array}$ & $\begin{array}{c}50.99 \\
\text { FDIS } \\
\text { approved for } \\
\text { publication }\end{array}$ \\
\hline $\begin{array}{l}60 \\
\text { Publication } \\
\text { stage }\end{array}$ & $\begin{array}{c}60.00 \\
\text { International } \\
\text { Standard } \\
\text { under } \\
\text { publication }\end{array}$ & & $\begin{array}{c}60.60 \\
\text { International } \\
\text { Standard } \\
\text { published }\end{array}$ & & & & \\
\hline $\begin{array}{l}90 \\
\text { Review } \\
\text { stage }\end{array}$ & & $\begin{array}{c}90.20 \\
\text { International } \\
\text { Standard } \\
\text { under } \\
\text { periodical } \\
\text { review }\end{array}$ & $\begin{array}{l}90.60 \\
\text { Close of } \\
\text { review }\end{array}$ & $\begin{array}{l}90.92 \\
\text { International } \\
\text { Standard to } \\
\text { be revised }\end{array}$ & $\begin{array}{c}90.93 \\
\text { International } \\
\text { Standard } \\
\text { confirmed }\end{array}$ & & $\begin{array}{c}90.99 \\
\text { Withdrawal of } \\
\text { International } \\
\text { Standard } \\
\text { proposed by } \\
\text { TC or SC }\end{array}$ \\
\hline $\begin{array}{l}95 \\
\text { Withdrawal } \\
\text { stage }\end{array}$ & & $\begin{array}{c}95.20 \\
\text { Withdrawal } \\
\text { ballot initiated }\end{array}$ & $\begin{array}{l}95.60 \\
\text { Close of } \\
\text { voting }\end{array}$ & $\begin{array}{c}95.92 \\
\text { Decision not } \\
\text { to withdraw } \\
\text { International } \\
\text { Standard }\end{array}$ & & & $\begin{array}{c}95.99 \\
\text { Withdrawal of } \\
\text { International } \\
\text { Standard }\end{array}$ \\
\hline
\end{tabular}

DIS $=$ draft international standard

FDIS $=$ final draft international standard

$\mathrm{SC}=$ subcommittee

$\mathrm{TC}=$ technical committee

*See http://www.iso.org/iso/home/standards_development/resources-for-technical-work/stages_table.htm 

APPENDIX C. STRUCTURE AND MANAGEMENT OF INTERNATIONAL ORGANIZATION FOR STANDARDIZATION TECHNICAL COMMITTEE 85 SUBCOMMITTEE AND WORKING GROUP MEMBERSHIP 



\section{APPENDIX C. STRUCTURE AND MANAGEMENT OF INTERNATIONAL ORGANIZATION FOR STANDARDIZATION TECHNICAL COMMITTEE 85 SUBCOMMITTEE AND WORKING GROUP MEMBERSHIP*}

$\underline{\text { Participating Countries (Standards Development }}$ $\underline{\text { Organizations) }}^{*}$

- Argentina (IRAM)

- Austria (ASI)

- Belgium (NBN)

- Bulgaria (BDS)

- Canada (SCC)

- China (SAC)

- Czech Republic (UNMZ)

- Finland (SFS)

- France (AFNOR)

- Germany (DIN)

- Hungary (MSZT)

- India (BIS)

- Italy (UNI)

- Japan (JISC)

- Kenya (KEBS)

- Korea, Republic of (KATS)

- Netherlands (NEN)

- Poland (PKN)

- Russian Federation (GOST R)

- Spain (AENOR)

- Sweden (SIS)

- Switzerland (SNV)

- United Kingdom (BSI)

- USA (ANSI) (very active in SC2)
Observing Countries (Standards Development Organizations)

- Cuba (NC)

- Egypt (EOS)

- Greece (ELOT)

- Indonesia (BSN)

- Iran, Islamic Republic of (ISIRI)

- Mongolia (MASM)

- Pakistan (PSQCA)

- Romania (ASRO)

- Slovakia (SUTN)

- South Africa (SABS)

- Thailand (TISI)

- Turkey (TSE)

- Ukraine (DSSU)

- Vietnam (STAMEQ)

Corresponding Country

- Hong Kong, China, (ITCHKSAR) does not yet have a fully developed national standards activity.

\footnotetext{
*Based on current records and author's observations:

Red $=$ very active

Blue $=$ moderately active

Black $=$ limited activity
}

\footnotetext{
*See

http://www.iso.org/iso/home/standards_development/list_of_iso_technical_committees/iso_technical_committee.ht $\mathrm{m}$ ? commid $=50266$
} 


\section{International Organization for Standardization (ISO) Technical Committee 85 (TC85), Subcommittee (SC) 2, "Radiation Protection, Structure, International Participation"}

- The voluntary secretariat for TC85 SC2 is Association Française de Normalisation (AFNOR), France.

- $\quad$ SC2 is composed of 13 working groups (WGs) managed by voluntary WG conveners.

- The voluntary conveners for the SC2 WGs include the following:

- WG2, "Reference radiations fields," Deutsches Institut für Normung (DIN), 17 professionals

- WG13, "Monitoring and dosimetry for internal exposure," DIN, 13 professionals

- WG14, "Air control and monitoring," American National Standards Institute (ANSI), 15 professionals

- WG17, "Radioactivity measurements," AFNOR, 25 professionals

- WG18, "Biological dosimetry," AFNOR, 10 professionals

- WG19, "Individual monitoring of external radiation," AFNOR, 20 professionals

- WG20, "Illicit trafficking in radioactive material," Austrian Standards Institute, unknown number of professionals

- WG21, "Dosimetry for exposures to cosmic radiation in civilian aircraft," AFNOR/British Standards Institute (BSI), 2 professionals

- WG22, "Dosimetry and related protocols in medical application of ionizing radiation," AFNOR, 9 professionals

- WG23, "Shielding and confinement systems for protection against ionizing radiation," AFNOR, 18 professionals

- WG24, "Remote handling devices for nuclear applications," AFNOR, 5 professionals

\section{ISO TC85 SC5, “Nuclear Fuel Cycle, Structure, International Participation”}

- The voluntary secretariat for TC85 SC5 is BSI(UK).

- $\mathrm{SC} 5$ is composed of 5 WGs managed by voluntary WG conveners.

- The voluntary conveners for the SC5 WGs include the following:

- WG1, "Analytical methodology in the nuclear fuel cycle," BSI, 16 professionals

- WG4, "Transportation of radioactive material," AFNOR, 18 professionals

- WG5, "Waste characterization," AFNOR, 21 professionals

- WG8, "Standardization of calculations, procedures and practices related to criticality safety," ANSI, 30 professionals

- WG13, "Decommissioning," BSI, 24 professionals

\section{ISO TC85 SC6, "Reactor Technology, Structure, International Participation”}

- The voluntary secretariat for TC85 SC6 is ANSI/ASTM International (Oak Ridge National Laboratory).

- SC6 is composed of 3 WGs managed by voluntary WG conveners.

- The voluntary conveners for the SC6 WGs include the following:

- WG1, "Decay heat power in light-water nuclear reactors," ANSI, 10 professionals

- WG2, "Technical specifications for research reactors," ANSI, 3 professionals

- WG3, "Power reactor siting, design, operation and decommissioning," AFNOR, 13 professionals 